\title{
Comparative Study of Changes in Haemodynamic Responses during Intubation- Intubating Laryngeal Mask Airway versus Endotracheal Tube
}

\author{
Saurabh Toppoํ․ Bharati $^{2}$ \\ ${ }^{1}$ Department of Anaesthesia, Hazaribagh Medical College and Hospital, Hazaribagh, Jharkhand, India. \\ 2Department of Anaesthesia, Rajendra Institute of Medical Sciences, Ranchi, Jharkhand, India.
}

\section{ABSTRACT}

\section{BACKGROUND}

Endotracheal intubation is one of the most invasive stimuli in anaesthesia ${ }^{1}$ producing noxious haemodynamic response in the form of tachycardia, hypertension and increased stress hormones i.e., catecholamine levels. ${ }^{1}$ This airway stimulus may increase morbidity and mortality in patients with recent myocardial infarction, hypertension, preeclampsia and cerebrovascular pathology such as tumours, aneurysms etc. Many pharmacological and non-pharmacological methods have evolved over time to obtund these haemodynamic stress responses to laryngoscopy and intubation. One such method is the use of Intubating Laryngeal Mask Airway (ILMA). In the present study, we compared changes in haemodynamic responses during intubation with endotracheal tube versus intubating with laryngeal mask airway.

\section{METHODS}

Fifty patients of either sex between 15-45 years were randomized in to two groups. Group I for ILMA ( $\mathrm{n}=25)$ and group II for Laryngoscopy and endotracheal intubation $(\mathrm{n}=25)$. Hemodynamic responses such as heart rate (HR), systolic blood pressure (SBP), diastolic blood pressure (DBP) were measured in either groups and compared at just before induction which was used as baseline, after intubation through ILMA/Laryngoscopy and at the end of 1, 2, 3, 5 and 10 minute intervals.

\section{RESULTS}

Both intubation through ILMA and laryngoscopy insertion were associated with increase in HR, SBP and DBP but in Group II Laryngoscopy group, the increase was $46.09 \%, 24.28 \%$ and $26.00 \%$ from baseline. The rise in HR, SBP and DBP were statistically significant $(\mathrm{p}<0.05)$ just after intubation through ILMA/laryngoscopy, it remained significant in the post intubation period till 5 minutes. After 5 and 10 minutes the changes in HR, SBP and DBP were not significant ( $p>0.05)$ between the groups.

\section{CONCLUSIONS}

In Group I ILMA insertion was carried out easily and laryngoscopy was not needed. ILMA insertion was associated with an attenuated pressor response in comparison with laryngoscopy and intubation. In Group II there was higher increase in pressor response to intubation than Group I because laryngoscopy was done. Haemodynamic responses such as HR, SBP, DBP were significantly less following ILMA insertion as compared to direct laryngoscopy. So ILMA appears to be more suitable in patients where pressor response is to be avoided as in high risk patients i.e. h/o recent myocardial infarction, hypertension, CAD, preeclampsia and cerebrovascular pathology such as tumours, aneurysms etc.

\section{KEY WORDS}

ILMA, Pressor Response, Heart Rate, Systolic Blood Pressure, Diastolic Blood Pressure
Corresponding Author:

Dr. Bharati,

Assistant Professor,

Department of Anaesthesia

Rajendra Institute of Medical Sciences,

Ranchi, Jharkhand, India.

E-mail: bharati.bediya@gmail.com

DOI: $10.14260 / \mathrm{jemds} / 2020 / 30$

Financial or Other Competing Interests: None.

How to Cite This Article:

Toppo S, Bharati. Comparative study of changes in haemodynamic responses during intubation- intubating laryngeal mask airway versus endotracheal tube. J. Evolution Med. Dent. Sci. 2020;9(03):134137, DOI: $10.14260 /$ jemds $/ 2020 / 30$

Submission 24-07-2019,

Peer Review 03-01-2020

Acceptance 09-01-2020,

Published 20-01-2020. 


\section{BACKGROUND}

Airway management is a fundamental and the most important aspect of anaesthetic practice and of emergency and critical care medicine. Endotracheal tube intubation (ETI) is the gold standard procedure for airway management. General anaesthesia with endotracheal intubation is a timetested procedure practiced all over the world. Direct laryngoscopy and intubation of trachea was considered safe until the hemodynamic stress response to airway manipulation, laryngoscopy and intubation was demonstrated by King et al. in 1951, which is characterized by an increase in HR and rise in BP. ${ }^{2}$ This is transient and insignificance in healthy individuals, but may be harmful in high risk patients such as patient with h/o hypertension or Ischaemic Heart Disease (IHD) and cerebrovascular diseases. Many pharmacological and non-pharmacological methods have evolved over time to attenuate this pressor response to airway manipulation, laryngoscopy and intubation. Use of Laryngeal Mask Airway (LMA) ${ }^{3}$ is one such method. The standard LMA is not an ideal intubation aid as the airway tube is too narrow to accommodate an adult diameter tracheal tube, too long to ensure that a normal length tracheal tube will reach the trachea and not sufficiently rigid to function as a guide to exact alignment of the mask with glottis. In addition, the mask aperture base may obstruct passage of tracheal tube. To overcome these limitations, ILMA has been developed. ${ }^{4}$ ILMA placement does not require any head manipulation and facilitate better alignment of tracheal tube, less distortion of the pharyngeal structure which leads to less airway stimulation with less haemodynamic changes. Hence, this prospective study was done with an objective to compare haemodynamic responses during endotracheal intubation using ILMA and Direct Laryngoscopy in adult patients.

\section{METHODS}

This randomized prospective study was done in RIMS, Ranchi, Jharkhand during 2006-2008. Patients of ASA grade I \& II of either sex aged between 15-45 years with Malampatti class I and II undergoing elective surgical procedures were included in this study. After obtaining approval from institutional ethical committee, written informed consent was taken. Routine investigations were done. Method chosen for allocation was simple random sampling. Patients were randomly distributed into both groups. Group I for ILMA insertion and intubation (ILMA group) $(n=25)$ and Group II for Direct laryngoscopy and endotracheal intubation (ETT group) $(n=25)$. Patients with Malampatti class $>$ III, morbid obesity, respiratory tract pathology, limited mouth opening, risk of aspiration/regurgitation, IHD, DM, COPD, and anticipated difficult airway were excluded from the study. After taking an informed consent, all patients were kept nil orally for at least 8 hours prior to surgery. Counselling was done regarding the type of the anaesthetic procedure. All patients in both groups were premedicated with diazepam $0.2 \mathrm{mg} / \mathrm{Kg}$ orally on the night prior to surgery. Inj. Ranitidine $50 \mathrm{mg}$, Metoclopramide $10 \mathrm{mg}$ intravenously and Glycopyrrolate $0.01 \mathrm{mg} / \mathrm{Kg}$ intramuscular half an hour prior to induction were given to all patients. When patients arrived in the operation theatre, they were placed in the supine position. All the patients were connected to multipara monitor and HR, NIBP, SpO2 and ECG were monitored. Intravenous line was secured. Baseline heart rate, blood pressure (systolic and diastolic) were recorded before induction of anaesthesia. All patients were pre-oxygenated for 3 minutes. Analgesia was achieved with Inj. Butorphanol $0.06 \mathrm{mg} / \mathrm{Kg}$ given I.V. Patients were induced with Inj. Propofol $2 \mathrm{mg} / \mathrm{Kg}$ and Inj. Vecuronium $0.1 \mathrm{mg} / \mathrm{Kg}$ was given I.V. In Group I, intubating laryngeal mask airway insertion was done followed by intubation, without laryngoscopy and in Group II, direct laryngoscopy followed by endotracheal intubation was done when relaxation was achieved. Single successful attempt of ILMA insertion/laryngoscopy and intubation was considered for this study, failed or repeated attempts were not considered. After intubation, bilateral air entry was confirmed by auscultation and the cuff was inflated. The ET tube was secured with an adhesive tape. After intubation, maintenance of anaesthesia was done with $66 \% \mathrm{~N}_{2} 0$ and $\mathrm{O}_{2} 33 \%$ and $0.5 \%$ Isoflurane with controlled ventilation. Adequate relaxation was maintained with intermittent bolus doses of Inj. Vecuronium. The study parameters - heart rate, blood pressure - both systolic and diastolic blood pressure were recorded before induction, after intubation using ILMA or Direct laryngoscopy and at $1^{\text {st }}$, $2^{\text {nd }}, 3^{\text {rd }}, 5^{\text {th }}$ and $10^{\text {th }}$ minutes of intubation in both Group I (ILMA) and Group II (direct laryngoscopy). At the end of the surgery, reversal was done with Inj. Neostigmine $0.05 \mathrm{mg} / \mathrm{Kg}$ + Glycopyrrolate $0.2 \mathrm{mg} / \mathrm{Kg}$. After proper thorough oral suctioning, patients were extubated and oxygenated with $100 \%$ oxygen after extubation by face mask.

\section{RESULTS}

This study included 50 patients of either sex admitted for various surgical procedures. They were divided into two groups of 25 and 25 patients each. Group I- ILMA insertion and endotracheal intubation Group II- Direct laryngoscopy and endotracheal intubation. All the values were expressed as mean \pm standard deviation (SD). Statistical analysis were done by repeated measure of variants followed by student's ' $\mathrm{t}$ ' test. A probability value of $\mathrm{p}<0.05$ was regarded as statistically significant. The demographic data of patients are shown in the following table.

\begin{tabular}{|c|c|c|}
\hline & Group I (n= 25) & Group II (n= 25) \\
\hline Age (Mean \pm SD) & $31.72 \pm 9.61$ & $30.32 \pm 12.38$ \\
\hline Weight (Mean \pm SD) & $55.76 \pm 8.51$ & $56.00 \pm 7.96$ \\
\hline Gender & & $11(44 \%)$ \\
\hline Male & $10(40 \%)$ & $14(56 \%)$ \\
\hline Female & $15(60 \%)$ & Table 1. Epidemiological Details of Patients \\
\hline \multicolumn{2}{|c|}{}
\end{tabular}

The groups were matched for their demographic data. Table 1 shows that the average age of patients in group I was 31.72 with a SD of 9.61 while it was 30.32 with a SD of 12.38 in group II and average weight of patients in group I was 55.76 with a SD of 8.51 while it was 56.00 with a SD of 7.96 . There was female preponderance in both groups with $60 \%$ in group I and $56 \%$ in group II. The haemodynamic changes of patients are shown in the following tables. Comparison of HR, SBP and DBP. 


\begin{tabular}{|c|c|c|c|c|c|c|}
\hline \multirow{3}{*}{$\begin{array}{c}\text { Time } \\
\text { Interval }\end{array}$} & \multicolumn{3}{|c|}{ Group I (ILMA) } & \multicolumn{3}{|c|}{ Group II (ETT) } \\
\hline & HR & SBP & DBP & HR & SBP & DBP \\
\hline & $\begin{array}{l}\text { Mean } \pm \\
\text { S.D. }\end{array}$ & $\begin{array}{l}\text { Mean } \pm \\
\text { S.D. }\end{array}$ & $\begin{array}{l}\text { Mean } \pm \\
\text { S.D. }\end{array}$ & $\begin{array}{l}\text { Mean } \pm \\
\text { S.D. }\end{array}$ & $\begin{array}{l}\text { Mean } \pm \\
\text { S.D. }\end{array}$ & $\begin{array}{l}\text { Mean } \pm \\
\text { S.D. }\end{array}$ \\
\hline $\begin{array}{l}\text { Just before } \\
\text { induction }\end{array}$ & $\begin{array}{l}85.32 \pm \\
8.46\end{array}$ & $\begin{array}{c}116.96 \pm \\
6.85\end{array}$ & $\begin{array}{c}74.32 \pm \\
4.60 \\
\end{array}$ & $\begin{array}{c}82.88 \pm \\
5.90 \\
\end{array}$ & $\begin{array}{c}116.56 \pm \\
7.10 \\
\end{array}$ & $\begin{array}{c}75.55 \pm \\
5.00\end{array}$ \\
\hline \begin{tabular}{|c|} 
After intubation \\
through ILMA/ \\
laryngoscopy \\
\end{tabular} & $\begin{array}{c}119.56 \pm \\
4.13\end{array}$ & $\begin{array}{c}140.36 \pm \\
5.05\end{array}$ & $\begin{array}{l}89.36 \pm \\
4.82\end{array}$ & $\begin{array}{c}121.08 \pm \\
9.68\end{array}$ & $\begin{array}{c}145.28 \pm \\
3.94\end{array}$ & $\begin{array}{c}95.20 \pm \\
3.91\end{array}$ \\
\hline After 1 minute & $\begin{array}{c}106.16 \pm \\
7.14\end{array}$ & $\begin{array}{c}136.68 \pm \\
4.68\end{array}$ & $\begin{array}{c}86.00 \pm \\
4.70 \\
\end{array}$ & $\begin{array}{c}14.76 \pm \\
9.11 \\
\end{array}$ & $\begin{array}{c}141.16 \pm \\
4.24\end{array}$ & $\begin{array}{c}92.24 \pm \\
4.01 \\
\end{array}$ \\
\hline After 2 minutes & $\begin{array}{c}100.88 \pm \\
6.61 \\
\end{array}$ & $\begin{array}{c}131.52 \pm \\
4.76 \\
\end{array}$ & $\begin{array}{c}83.28 \pm \\
4.76 \\
\end{array}$ & $\begin{array}{c}107.44 \pm \\
8.66 \\
\end{array}$ & $\begin{array}{c}137.04 \pm \\
4.61 \\
\end{array}$ & $\begin{array}{c}89.36 \pm \\
4.15 \\
\end{array}$ \\
\hline After 3 minutes & $\begin{array}{c}94.92 \pm \\
5.92 \\
\end{array}$ & $\begin{array}{c}125.72 \pm \\
5.13 \\
\end{array}$ & $\begin{array}{c}80.96 \pm \\
4.58 \\
\end{array}$ & $\begin{array}{l}97.04 \pm \\
8.19 \\
\end{array}$ & $\begin{array}{c}131.20 \pm \\
5.11 \\
\end{array}$ & $\begin{array}{c}85.60 \pm \\
4.50 \\
\end{array}$ \\
\hline After 5 minutes & $\begin{array}{c}85.36 \pm \\
7.34\end{array}$ & $\begin{array}{c}117.84 \pm \\
5.56\end{array}$ & $\begin{array}{c}74.16 \pm \\
4.50\end{array}$ & $\begin{array}{c}90.72 \pm \\
7.22\end{array}$ & $\begin{array}{c}125.04 \pm \\
4.83\end{array}$ & $\begin{array}{c}81.76 \pm \\
4.73\end{array}$ \\
\hline $\begin{array}{l}\text { After } 10 \\
\text { minutes }\end{array}$ & $\begin{array}{c}85.12 \pm \\
6.53 \\
\end{array}$ & $\begin{array}{c}115.80 \pm \\
6.49 \\
\end{array}$ & $\begin{array}{c}72.56 \pm \\
3.62 \\
\end{array}$ & $\begin{array}{c}85.56 \pm \\
6.78 \\
\end{array}$ & $\begin{array}{c}116.80 \pm \\
6.25 \\
\end{array}$ & $\begin{array}{c}75.84 \pm \\
4.93 \\
\end{array}$ \\
\hline & & $R, S B$ & $D B$ & Vari & & als in \\
\hline
\end{tabular}

\begin{tabular}{|c|c|c|c|c|c|c|}
\hline \multirow{2}{*}{ Time Interval } & \multicolumn{2}{|c|}{ HR } & \multicolumn{2}{c|}{ SBP } & \multicolumn{2}{c|}{ DBP } \\
\cline { 2 - 7 } & $\begin{array}{c}\text { t- } \\
\text { Value }\end{array}$ & $\begin{array}{c}\text { p- } \\
\text { Value }\end{array}$ & $\begin{array}{c}\text { t- } \\
\text { Value }\end{array}$ & $\begin{array}{c}\text { p- } \\
\text { Value }\end{array}$ & $\begin{array}{c}\text { t- } \\
\text { Value }\end{array}$ & $\begin{array}{c}\text { p- } \\
\text { Value }\end{array}$ \\
\hline Just before induction & 1.69 & $>0.05$ & 0.12 & $>0.05$ & 0.52 & $>0.05$ \\
\hline $\begin{array}{c}\text { After intubation through } \\
\text { ILMA/laryngoscopy }\end{array}$ & 5.78 & $<0.05$ & 8.34 & $<0.05$ & 5.60 & $<0.05$ \\
\hline After 1 minute & 4.88 & $<0.05$ & 6.33 & $<0.05$ & 4.11 & $<0.05$ \\
\hline After 2 minutes & 3.45 & $<0.05$ & 4.22 & $<0.05$ & 2.56 & $<0.05$ \\
\hline After 3 minutes & 2.09 & $<0.05$ & 3.64 & $<0.05$ & 2.05 & $<0.05$ \\
\hline After 5 minutes & 1.19 & $<0.05$ & 2.85 & $<0.05$ & 1.98 & $<0.05$ \\
\hline After 10 minutes & 0.39 & $>0.05$ & 0.57 & $>0.05$ & 0.58 & $>0.05$ \\
\hline Table 3. Statistical Comparison of HR, SBP and DBP at Various Time \\
Intervals between Both Groups \\
\hline
\end{tabular}

In Tables 2, 3, 4, Mean \pm S.D. and statistical comparison of HR, SBP, DBP at various time intervals in both groups showed an increase in HR, SBP, DBP in both groups after intubation through ILMA/Laryngoscopy but in Group II, increase in HR, SBP, DBP at $1,2,3$, and 5 minutes were statistically significant $(\mathrm{p}<0.05)$ and after 10 minutes statistically not significant $(p>0.05)$ when compared to group I.

\section{DISCUSSION}

Any airway manipulation, particularly by laryngoscopy and endotracheal intubation, changes cardiovascular physiology both via reflex responses and the physical presence of an endotracheal tube ${ }^{1}$. Although these are only transient cardiovascular stress responses, but they are life threatening to the patients suffering from the cardiovascular and cerebrovascular diseases. Mechanical stimulation of oropharyngolaryngeal structures caused by laryngoscopy and tracheal intubation is considered as the major cause of the haemodynamic responses to laryngoscopy and tracheal intubation ${ }^{5,6}$. Many studies have done to attenuate or avoid the mechanical stimuli for intubation.

ILMA is a newly developed airway-securing device in clinical practice ${ }^{7,8}$. It offers the same advantage in facilitating lung ventilation as that with standard LMA, but also it provides the superior function as an aid to the orotracheal intubation. ILMA can also be used for difficult intubation and airway management in emergencies to ventilate the patients timely and effectively. In our study, the pre-induction heart rates (HR), systolic blood pressures (SBP) and diastolic blood pressures were statistically comparable ( $p>0.05$ ). In post ILMA insertion followed by intubation i.e., Group I, the increase in HR, SBP and DBP were $40.13 \%, 20.35 \%$ and $20.23 \%$ from baseline. In post direct laryngoscopy and intubation i.e., Group II, the increase was $46.09 \%$, 24.28\% and $26.00 \%$ from baseline. The rise in HR, SBP and DBP were statistically significant $(\mathrm{p}<0.05)$ just after intubation through ILMA/laryngoscopy, it remained significant in the post intubation period till 5 minutes. After 5 and 10 minutes the changes in HR, SBP and DBP were not significant $(p>0.05)$ between group analysis. In within group analysis, significant changes in HR, SBP and DBP $(p<0.05)$ were observed after intubation through ILMA i.e., Group I from baseline, it remained significant at 1,2 and 3 minutes $(p<0.05)$. At 5 - and 10-minute interval there were no significant changes from baseline ( $p>0.05$ ). In Group II significant changes in HR, SBP and DBP from baseline were seen just after intubation through laryngoscopy, it remained significant at 1, 2, 3 and 5 minutes $(p<0.05)$. At 10 minutes interval there were no significant changes from baseline ( $p>0.05)$.

These findings are similar to other studies done earlier by Naveed et al, ${ }^{9}$ Bharti et al,10 Wilson et al, ${ }^{11}$ Khal et al. ${ }^{12}$ Baskett and colleagues ${ }^{13}$ also studied the haemodynamic responses after intubation aided through ILMA and found that ILMA-guided orotracheal intubation produced statistically less haemodynamic responses but these responses are not clinically significant. In the study of Joo and Rose, ${ }^{14}$ mean arterial pressure was higher in the patients who received laryngoscopic orotracheal intubation than that in those received ILMA-guided orotracheal intubation. One of the prominent advantages of ILMA - guided orotracheal intubation is that it will not stimulate mechanically any anatomical structures i.e., base of the tongue, epiglottis, and the receptors in the pharyngeal muscles. Therefore, ILMAguided orotracheal intubation produces less adverse cardiovascular stress responses.

Several investigators have studied and reached to a conclusion that laryngoscopy is the main etiological factor for haemodynamic response associated with endotracheal intubation. ${ }^{15,16,17,18}$

Our study showed that maximum increase in HR, SBP and DBP were higher in group-II (Direct laryngoscopy) than in group - I (Intubation through the ILMA). The reason might be that there is less mechanical pressure applied on pharyngeal structures during intubation through the ILMA.

\section{CONCLUSIONS}

In Group I, ILMA insertion was carried out easily and laryngoscopy was not needed. ILMA insertion in fit patients was associated with an attenuated pressure response in comparison with direct laryngoscopy and intubation. In Group II there was higher increase in pressor response to intubation than Group I because laryngoscopy was done to aid intubation which is the main factor for pressor response to intubation. HR, SBP and DBP reached baseline at 5 minutes in Group I and at 10 minutes in Group II. So, ILMA appears to be more suitable in patients where pressor response is to be avoided. 


\section{ACKNOWLEDGEMENT}

Authors thank Dr. J. Prasad, Professor and H.O.D. and Dr. Ajit Kumar, Professor, RIMS, Ranchi.

\section{REFERENCES}

[1] Kaymak C, Kocabas NA, Durmaz E, et al. Beta2 Adrenoreceptor (ADRB2) pharmacogenetics and cardiovascular phenotypes during laryngoscopy and tracheal intubation. Int J Toxicol 2006;25 (6):443-9.

[2] King BD, Harris LC, Greefenstein FE, et al. Reflex circulatory responses to direct laryngoscopy and tracheal intubation performed during general anaesthesia. Anaesthesiology 1951;12 (5):556-66.

[3] Brain AI. The laryngeal mask - a new concept in airway management. Br J Anaesth 1983;55 (8):801-5.

[4] Brain AI, Verghese C, Addy EV, et al. The intubating laryngeal mask: I. Development of a new device for intubation of the trachea. Br J Anaesth 1997;79 (6):699703.

[5] Kirvela M, Scheinin M, Lindgren L. Haemodynamic and catecholamine responses to induction of anaesthesia and tracheal intubation in diabetic and non-diabetic uraemic patients. BJA 1995;74 (1):60-5.

[6] Houghton IT, Low JM, Lau JT, et al. An ethnic comparison of the sympathetic response to tracheal intubation. Anaesthesia 1993;48 (11):965-8.

[7] Brain AI, Verghese C, Addy EV, et al. The Intubating laryngeal mask: II. A Preliminary clinical report of a new means of intubating the trachea. Br J Anaesth 1997;79 (6):704-9.

[8] Shribman AJ, Smith G, Achola KJ. Cardiovascular and catecholamine responses to laryngoscopy with and without tracheal intubation. Br J Anaesth 1987;59 (3):295-9.
[9] Naveed TS, Fazal HK, Haemodynamic response to tracheal intubation via Intubating laryngeal mask airway versus laryngoscopic tracheal intubation. J Pak Med Assoc 2007;57 (1):11-4.

[10] Bharti N, Naik AK. Ease of insertion and haemodynamic effects following tracheal intubation using intubating laryngeal mask airway: a comparison with conventional Macintosh Laryngoscope. Indian J Anaesth 2006;50 (3):205-8.

[11] Wilson IG, Fell D, Robinson SL, et al. Cardiovascular responses to insertion of the laryngeal mask. Anaesthesia 1992;47 (4):300-2.

[12] Kahl M, Eberhart LH, Behnke H, et al. Stress response to tracheal intubation in patients undergoing coronary artery surgery: direct laryngoscopy versus intubating laryngeal mask airway. J Cardiothoracic Vasc Anesth 2004;18 (3):275-80.

[13] Baskett PJ, Parr MJ, Nolan JP. The intubating laryngeal mask airway: results of a multicenter trial with experience of 500 cases. Anaesthesia 1998;53 (12):1174-9.

[14] Joo H, Rose K. Fastrach: a new intubating laryngeal mask airway: successful use in patients with difficult airways. Can J Anaesth Analg 1998;45 (3):253-6.

[15] Kaul TK, Valech V, Kathuria S, et al. Catecholamine response to endotracheal intubation and laryngeal mask airway insertion. Ind J Anesth 1999;43:30-2.

[16] Bukhari SA, Naqash I, Zargar J, et al. Pressor responses and intraocular pressure changes following insertion of laryngeal mask airway: comparison with tracheal tube insertion. Ind J Anaesth 2003;47 (6):473-5.

[17] Montazari K, Naghibi KH, Hashemi SJ. Comparison of haemodynamic changes after insertion of LMA, facemask and endotracheal intubation. Acta Medica Iranica 2004;42 (6):437-40.

[18] Tabari M, Alipour M, Ahmadi M. Hemodynamic changes occurring with tracheal intubation by direct laryngoscopy compared with intubating laryngeal mask airway in adults: a randomized comparison trial. Egyptian Journal of Anaesthesia 2013;29:103-7. 